\title{
Two new species of Anurophorinae (Collembola: Isotomidae) from Magadan Region
}

\section{Ава новых вида Anurophorinae (Collembola: Isotomidae) из Магаданской области}

\author{
Anatoly B. Babenko', Mikhail B. Potapov ${ }^{2}$ \\ А.Б. Бабенко ${ }^{1}$, М.Б. Потапов ${ }^{2}$

\footnotetext{
${ }^{1}$ Severtsov Institute of Ecology \& Evolution, Russian Academy of Sciences, Leninski pr. 33, Moscow 119071, Russia. E-mail: 1sdc@mail.ru ${ }^{1}$ Институт проблем экологии и эволюции РАН им. А.Н. Северцова, Ленинский пр. 33, Москва 119071, Россия.

${ }^{2}$ Moscow State Pedagogical University, Kibalchich str. 6, build. 5, Moscow 129164, Russia. E-mail: mpnk@orc.ru

${ }^{2}$ Московский педагогический государственный университет, ул. Кибальчича, д. 6, корп. 5, Москва 129164, Россия.
}

KEY WORDS: Collembola, Isotomidae, Weberacantha, Scutisotoma, new species, Russia.

КЛЮЧЕВЫЕ СЛОВА: Collembola, Isotomidae, Weberacantha, Scutisotoma, новый вид, Россия.

ABSTRACT. The paper provides descriptions of Weberacantha striganovae sp.n. and Scutisotoma postertriplex sp.n. The list of the principal publications on the descriptions of Collembola from north-eastern parts of Russia is given.

РЕЗЮМЕ. В работе приведены описания Weberacantha striganovae sp.n. и Scutisotoma postertriplex sp.n. Приводится список основных работ, связанных с описаниями коллембол на северо-востоке России.

\section{Introduction}

Increased diversity among many animal and plant taxa in north-eastern parts of Russia is a well-known fact. The springtail fauna of the region is not an exception being also rather diverse and highly original. Nevertheless its inventory is obviously far from complete despite notable number of original species descriptions from the region [Schött, 1893; Martynova, 1969, 1970 1976, 1977, 1978, 1981; Martynova et al., 1973, 1977; Martynova \& Bondarenko, 1978; Tshelnokov, 1977, 1987, 1988, 1990; Tshelnokov \& Bondarenko, 1978; Fjellberg, 1985, 1987; Deharveng, 1987; Babenko, 1994; Potapov, 1997a, b; Potapov \& Babenko, 2000; Bretfeld, 2000; Pomorski, 2001; Kaprus' \& Pomorski, 2008 and some others]. The present paper devoted to descriptions of two new species from two different but closely related genera [see Potapov et al., 2006] of Anurophorinae is based on material collected in upper reaches of Ola River $(\sim 120 \mathrm{~km}$ north from Magadan, $\left.60^{\circ} 39^{\prime} \mathrm{N}, 151^{\circ} 61^{\prime} \mathrm{E}\right)$.

The types of the new species are deposited in the collection of the Department of Zoology \& Ecology, Moscow State Pedagogical University (MSPU).

ABBREVIATIONS: Abd.I-VI - abdominal segments; Ant.1-4 - antennal subsegments; bms — basal microsensillum; $m s$ - microsensillum; MSPU — Moscow State Pedagogical University; PAO — postantennal organ; $p$-row - posterior setal row on tergites; $s-$ sensillum; Th.I-III - tergal segments; Ti.1-3 - tibiotarsi of legs; $\mathrm{U}_{3}$ - unguis of leg 3. Notation of setae of femur $(a, a e, e, p e-p-p i-i)$ is given after Huang \& Potapov (in press).

\section{Weberacantha striganovae sp.n.} Figs 1-9.

TYPE MATERIAL: Holotype, subadult female, North East of Russia, upper reachers of Ola River, $\sim 120 \mathrm{~km}$ north from Magadan, nival slope with Oxyria digina, $1023 \mathrm{~m}$ alt., 11.09.2011, leg. A. Babenko (MSPU). Paratypes, adult females, subadult females and males, juveniles: 30 specimens on slides and 25 specimens in alcohol, ibidem (MSPU).

DESCRIPTION. Size up to $1.3 \mathrm{~mm}$ (the largest subadult female). Body cylindrical (Fig. 1). Abdominal tip cryptopygic: Abd.VI hidden under the convex and wrinkled Abd.V. Colour blue-violet, extremities paler. Cuticle strongly reticulated, the largest granules elongated, 1.5 longer then common seta socket diameter at posterior edge of Abd.IV. Ocelli 8+8, $\mathrm{G}$ and $\mathrm{H}$ smaller (Fig. 4). PAO narrow, with indistinct constriction, 1.11.3 as long as $\mathrm{U}_{3}$, a little shorter than Ant.1 width (0.81.0), three times longer than nearest ocellus (Fig. 4). Maxillary outer lobe with 4 sublobal hairs and bifurcate palp. Maxillary head with short, unmodified lamellae. Labral chaetotaxy as 4/5,5,4. Labium with 3 proximal and 4 basomedian chaetae, papilla $E$ with full set of guards ( $e 7$ present). Ventral side of head normally with $5+5$ postlabial chaetae. Ant. 1 with 11 chaetae, 2 basal microsensilla $(b m s)$ and 2 sensilla $(s)$. Ant. 2 with $3 \mathrm{bms}$ and $1 \mathrm{~s}$, Ant. 3 with $1 \mathrm{bms}$ and 6 distal $s$, including two lateral sensilla always present in adults and subadults of both sexes, as well as in middle-sized juveniles. Sensilla on Ant.4 weakly differentiated, subapical organite very small, roundish. 


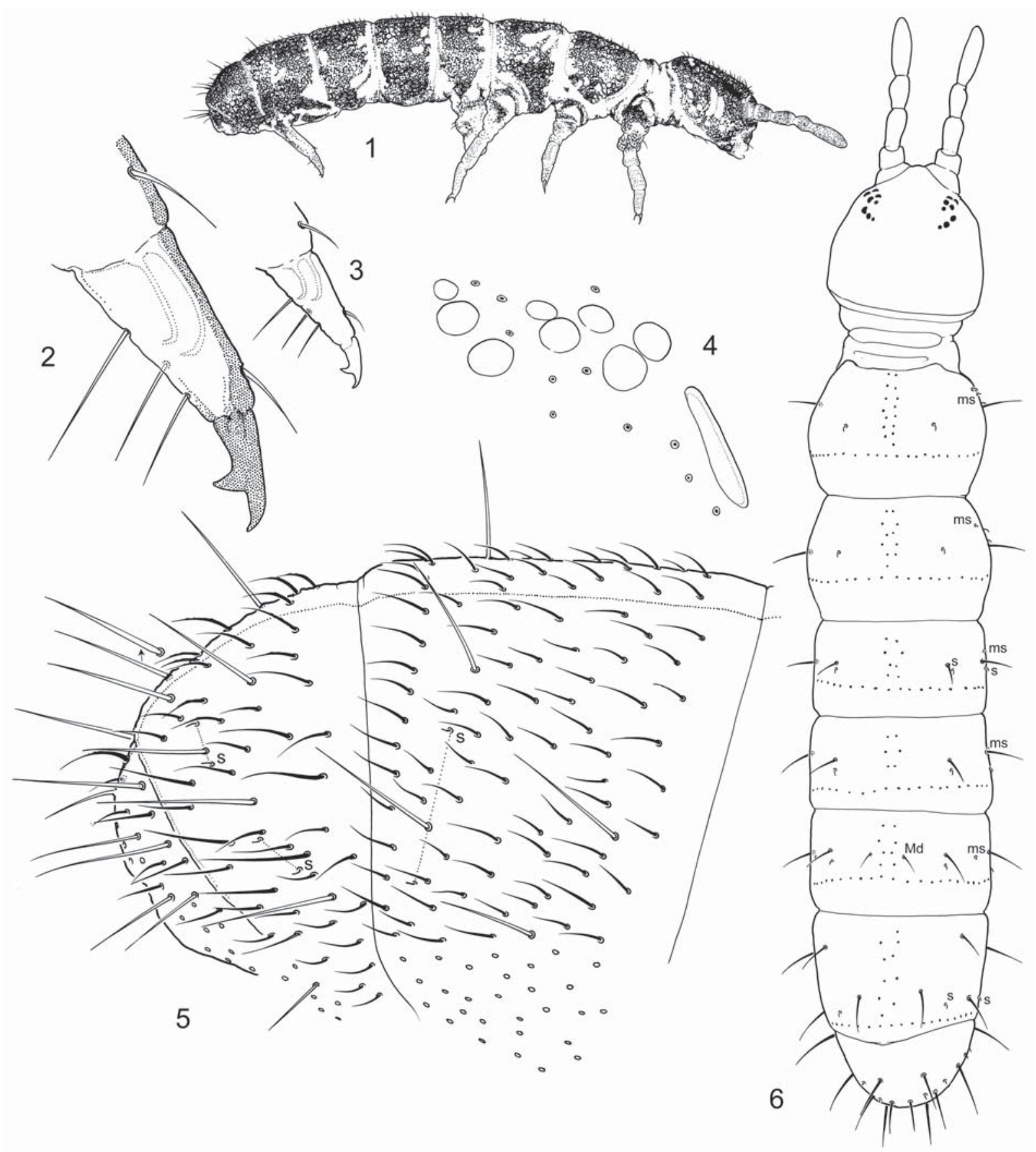

Figs 1-6. Weberacantha striganovae sp.n.: 1 - coloration; 2-3 - distal half of furca in adult (2) and juvenile individual of $0.6 \mathrm{~mm}$ size (3), lateral view; 4 - ommatidia and PAO; 5 - chaetotaxy of Abd.IV-VI; 6 - arrangement of sensilla, microsensilla and macrochaetae on body. $M d$ - dorsal macrochaeta, $s$ - (macro)sensillum, $m s$ - microsensillum.

Рис. 1-6. Weberacantha striganovae sp.n.: 1 - окраска; 2-3 - дистальная половина прыгательной вилки у половозрелой (2) и молодой особи размером 0,6 мм (3), вид сбоку; 4 - глазки и постантеннальный орган; 5 - хетотаксия IV-VI сегментов брюшка; 6 - расположение сенсилл, микросенсилл и крупных щетинок на теле. $M d-$ спинная макрощетинка, $s$ - (макро)сенсилла, $m s-$ микросенсилла.

Dorsal axial chaetom of Th.II-Abd.III as 7-10,5-7/ 4-5,4-6,4-5. Common chaetae thick, most of them moderately serrated on dorsal side of Abd. V (Fig. 5). Thorax without ventral axial chaetae. Macrochaetae pointed, clearly differentiated (Figs 5, 6). Abd.V with several straight and slightly thickened dorsal macro- chaetae, about $0.5-0.6$ as long as tergite. Abd.IV with 4 macrochaetae of subequal size on each side (Fig. 5). Number of macrochaetae on Th.II-Abd.III 1,1/2,2,2+1* (Fig. 6), dorsal macrochaetae on Abd.III weakly developed (notated as $1^{*}$ in formula). Sensilla on tergites clearly differentiated, significantly shorter and thinner 

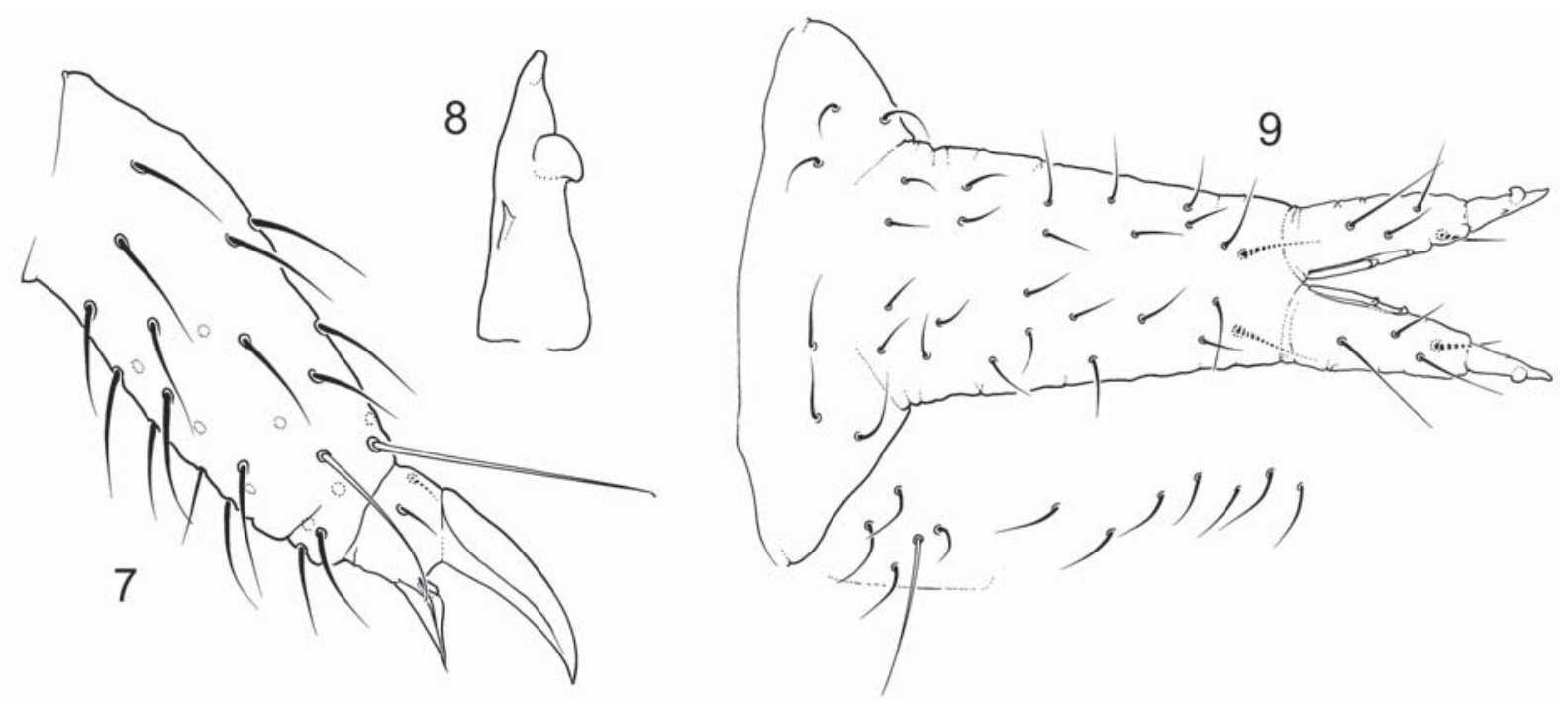

Figs 7-9. Weberacantha striganovae sp.n.: 7 - tibiotarsus of Leg 3; 8 - mucro, posterior view; 9 - furcal area, posterior view.

Рис. 7-9. Weberacantha striganovae sp.n.: 7 - голенелапка третьей пары ног; 8 - мукро, вид с задней стороны; 9 - поле прыгательной вилки, вид с задней стороны.

than ordinary chaetae. Sensillar formula 3,3/2,2,2,2,4 $(\mathrm{s}), 1,1 / 1,1,1(\mathrm{~ms})$ (Fig. 6). Microsensilla positioned in front of lateral sensilla on Abd.I and II, between lateral and medial sensilla on Abd.III (Fig. 6). Sensilla on Abd.I-III in mid-tergal position. Medial and lateral pairs of sensilla on Abd. V similar in size and set in a transversal line (Fig. 5).

Unguis strong, slightly curved, without inner tooth (Fig. 7). Unguiculus about half as long as unguis (2.0 2.3). Ti.1-3 with $21,21,25-28$ chaetae. B-row of chaetae on Ti.1-2 complete. Tibiotarsal tenent chaetae (12-2 on Ti.1-3) clavate, 1.2-1.6 as long as $U_{3}$. Femur 1 with $5 a$-chaetae, $1 a e$-chaeta, $3 e$-chaetae, and 8 (more rarely 7 or 9) chaetae of $p e-p$-pi-i-group. Upper and lower subcoxa with 2 and 6-8 chaetae on Leg 2 and 57 and 7-9 on Leg 3. Ventral tube with 4+4 laterodistal and 6-7 posterior chaetae. Tenaculum with $4+4$ teeth and 1 chaeta. Anterior furcal subcoxa with 7-10, posterior one with 5 chaetae (Fig. 9). Anterior side of manubrium with a pair of chaetae which also present in juvenile individuals if not of first instar (Figs 2-3). Posterior side with $8-11+8-11$ on the main part and $3+3$ chaetae on laterobasal lobes (Fig. 9). Dens anteriorly with 1 distal chaeta, posterior side almost smooth, with 3 chaetae. Mucro massive, with two strong teeth and one small denticle on inner side, the latter well visible only in dorso-ventral position of mucro, if lateral it normally hardly identifiable (Figs 8-9). Lamellae not differentiated. Ratio of manubrium : dens : mucro $=$ 3.6-4.7 : 1.6-2.0: 1 .

DISCUSSION. The genus being monotypic for many years includes now 6 species ( 7 with the new one). They represent a rather homogeneous group which inhabits remote mountainous regions of Eastern Asia (Nepal, Mongolia, and different parts of Siberia). Only the type species of the genus, $W$. octa Christiansen, 1951, is mainly Nearctic but also recorded from East
Chukotka [Potapov, 2001]. Due to strong straight abdominal macrochaetae, $W$. striganovae sp.n. is very similar to $W$. echinodermata Potapov et al., 2006 from Yakutia and W. cylindrica Huang et Potapov, 2012, recently described on material from Khabarovsk Territory. These three species can be distinguished by the following more or less stable characters:

W. striganovae sp.n. is also characterized by the presence of denticle on inner side of mucro (absent in

\begin{tabular}{|l|c|c|c|c|}
\hline species & $\begin{array}{c}\text { a pair of } \\
\text { chaetae } \\
\text { on } \\
\text { anterior } \\
\text { side of } \\
\text { manu- } \\
\text { brium }\end{array}$ & $\begin{array}{c}\text { chaeto- } \\
\text { taxy of } \\
\text { dens }\end{array}$ & $\begin{array}{c}\text { macro- } \\
\text { chaetae } \\
\text { on } \\
\text { Abd.I- } \\
\text { III }\end{array}$ & $\begin{array}{c}\text { Latero- } \\
\text { distal } \\
\text { chaetae } \\
\text { on } \\
\text { ventral } \\
\text { tube }\end{array}$ \\
\hline $\begin{array}{l}\text { W. echi- } \\
\text { noder- } \\
\text { mata }\end{array}$ & + & $3 / 4-5$ & $1,1,1$ & $6+6$ \\
\hline $\begin{array}{l}\text { W. cylin- } \\
\text { drica }\end{array}$ & - & $0 / 2$ & $1+1^{*}, 2,2$ & $4+4(3+3)$ \\
\hline $\begin{array}{l}\text { W. stri- } \\
\text { ganovae } \\
\text { sp.n. }\end{array}$ & + & $1 / 3$ & $2,2,2+1 *$ & $4+4$ \\
\hline
\end{tabular}

* weakly developed

two other species). This difference is of lower value since $W$. echinodermata possesses a rudimentary ridge in associated side of mucro which can also be interpreted as a denticle.

DISTRIBUTION AND ECOLOGY. The species is known only from the type locality. Four «spiny» species (striganovae, echinodermata, cylindrica, octa) inhabit more eastern areas of Asia than other congeners.

NAME DERIVATION. Honours Bella R. Striganova, a prominent Russian soil biologist and ecologist, on the occasion of her 80th birthday. 


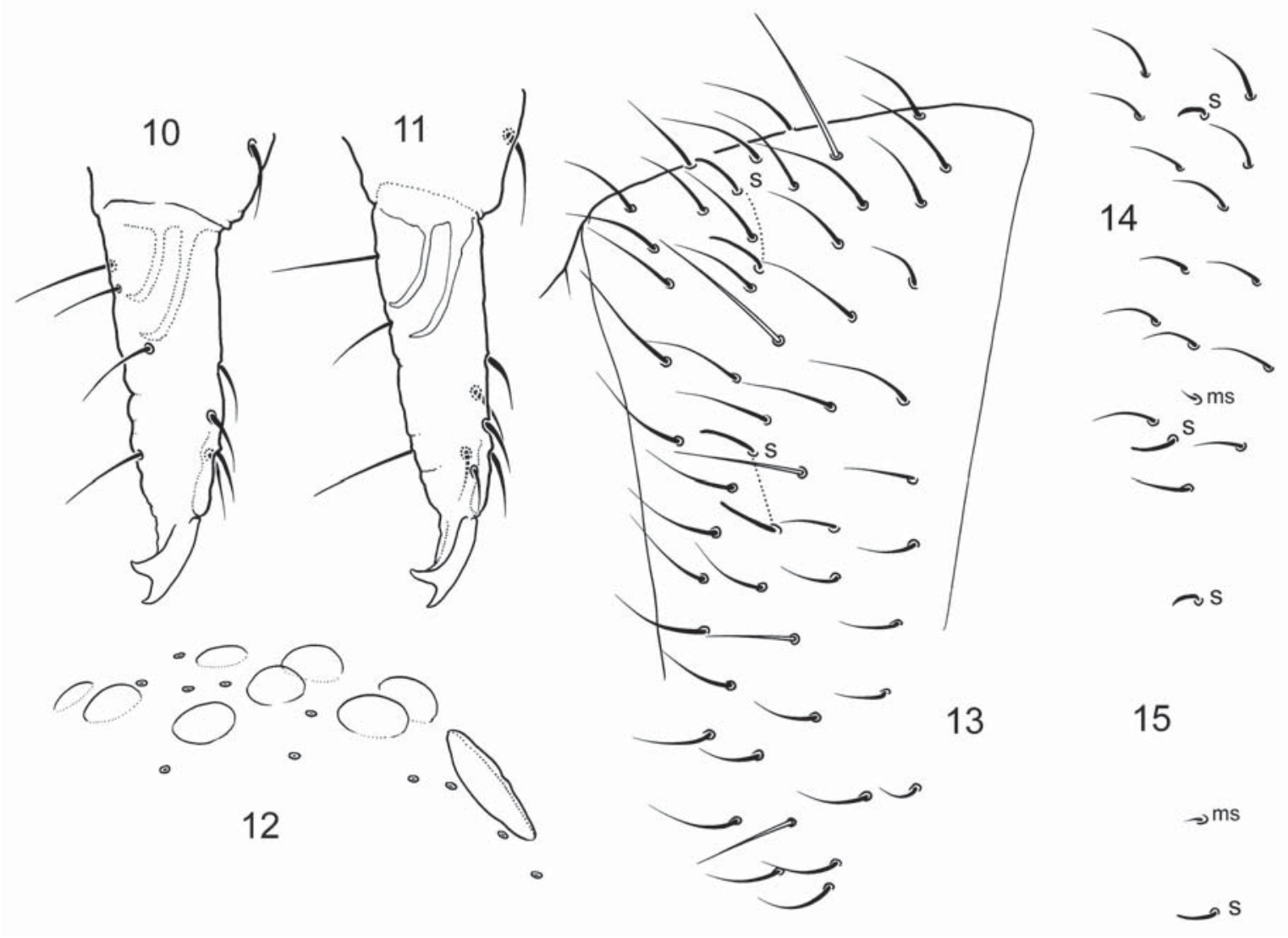

Figs 10-14. Scutisotoma postertriplex sp.n.: 10-11 - distal half of furca, right (10) and left (11) parts of dens in one of the paratypes; 12 - ommatidia and PAO; 13 - chaetotaxy of Abd.V; $14-15$ - lateral area of Abd.III, arrangement of $s$ and $m s$, variation. $s-$ (macro)sensillum, $m s$ - microsensillum.

Figs 10-14. Scutisotoma postertriplex sp.n.: 10-11 - дистальная половина прыгательной вилки, правая (10) и левая (11) части денс одного из паратипов; 12 - глазки и постантеннальный орган; 13 - хетотаксия $\mathrm{V}$ сегмента брюшка; $14-15$ - латеральный участок III сегмента брюшка, расположение $s$ и $m s$, варианты. $s$ - (макро)сенсилла, $m s$ - микросенсилла.

\section{Scutisotoma postertriplex sp.n.}

Figs 10-14.

TYPE MATERIAL: Holotype, adult male, North East of Russia, upper reachers of Ola River, $\sim 120 \mathrm{~km}$ north from Magadan, $1145 \mathrm{~m}$ alt., 7-14.08.2011, from pitfall traps in snowfield, leg. A. Babenko (MSPU). Paratypes: one adult female, subadult females and males, juveniles: 12 specimens on slides and 20 specimens in alcohol, ibidem and in different mountain tundra sites nearby, all above $1100 \mathrm{~m}$ alt, from pitfall traps and samples extracted with Tullgren funnels (MSPU).

DESCRIPTION. Size from 0.6 to $0.75 \mathrm{~mm}$ (adult male and female, respectively). Body of normal shape. Colour blue-violet, extremities paler. Cuticle reticulation thin and regular. Ocelli 8+8, $\mathrm{G}$ and $\mathrm{H}$ smaller (Fig. 12). PAO elliptical, with indistinct constriction, 0.91.2 as long as $\mathrm{U}_{3}$, shorter than Ant.1 width (0.6-0.7), $2-3$ times longer than nearest ocellus. Maxillary outer lobe with 4 sublobal hairs and bifurcate palp. Maxillary head with short, unmodified lamellae. Labral chaetotaxy as $4 / 5,5,4$. Labium with 3 proximal and 4 basomedian chaetae, papilla $E$ with full set of guards (e 7 present). Ventral side of head with $4+4-5+5$ postlabial chaetae. Ant. 1 with 11 chaetae, 2 basal microsensilla (bms) and 2 sensilla (s). Ant.2 with 3 bms and $1 \mathrm{~s}$, Ant. 3 with $1 \mathrm{bms}$ and 6 distal $s$ (including two lateral). Sensilla on Ant.4 weakly differentiated, subapical organite very small, roundish.

Dorsal axial chaetom of Th.II-Abd.III as 7-9,5-6/ 4-5,4-5,4-5. Common chaetae rather thin, not serrated (Fig. 13). Thorax without ventral axial chaetae. Macrochaetae pointed, hardly differentiated. On Abd.V and VI dorsal macrochaetae better developed, $0.3-0.45$ as long as tergite. Sensilla on tergites clearly differentiated, slightly shorter than ordinary chaetae, of the same width. Sensillar formula 3,3/2,2,2,2,4 (s), 1,1/1,1,1 ( $m s$ ). On Abd III microsensilla positioned between lateral and medial sensilla, normally close to lateral ones (Figs 14-15). Sensilla on Abd.I-III in mid-tergal position. Medial and lateral pairs of sensilla on Abd.V similar in size and set usually in a transversal line (Fig. 13).

Unguis without teeth. Unguiculus longer than half of unguis (1.6-1.8). Ti.1-3 with 21,21,26-27 chaetae. B-row of chaetae on Ti.1-2 complete. Tibiotarsal tenent chaetae (1-2-2 on Ti.1-3) weakly developed, blunt, 0.8-1.1 as long as $\mathrm{U}_{3}$. Femur 1 with $5 a$-chaetae, $1 a e$ chaeta, $3 e$-chaetae, and 7 chaetae of pe-p-pi-i-group. 
Upper and lower subcoxa with 1 and 6 chaetae on Leg 2 and $4-5$ and 6-8 on Leg 3. Ventral tube with $4+4$ laterodistal and 6-7 posterior chaetae. Tenaculum with $4+4$ teeth and 1 chaeta. Anterior furcal subcoxa with $13-15$, posterior one with 7-8 chaetae. Anterior side of manubrium with a pair of chaetae. Posterior side with $10-11+10-11$ on the main part and $4+4$ chaetae on laterobasal lobes. Dens anteriorly with 5-6 (rarely 4) chaetae in distal half, posterior side with 3 (rarely 4) chaetae. Mucro bidentate (Figs 10-11). Lamellae not differentiated. Ratio of manubrium : dens : mucro $=$ $5.0-7.0: 2.5-3.5: 1$.

DISCUSSION. Following the most comprehensive key of the genus mainly covered Palaearctic and north Nearctic congeners [Potapov et al., 2006], Magadan specimens will key to $S$. millimetrica Potapov et al., 2006 described from Khabarovsk Territory. However, the latter species sharing many common features with S. postertriplex sp.n. is characterized by different chaetotaxy of dens (6-8/7 in millimetrica ver. 5-6/3-4 in the new species). It should be noted that a proportion found in dental chaetotaxy of $S$. postertriplex sp.n., i.e. a strong reduction of posterior but not anterior chaetae, is not usual for the genus. Thus, all so far known congeners having only 2-4 posterior chaetae on dens, namely, dodecocellata, montana, stachanoremi, baica, indigirka, possess none or only one anterior chaetae.

DISTRIBUTION AND ECOLOGY. The species is common in mountain tundra belt of the type locality.

NAME DERIVATION. The species is well characterized with three posterior chaetae on dens.

ACKNOWLEDGEMENTS. We would like to express our sincere thanks to O.L. Makarova and D.I. Berman for their valuable assistance during field works. The paper has been supported through grants of the Russian Foundation for Basic Research (\#\# 11-0401725, 11-04-00941, and 11-04-91179-GFENa) and through several scientific programmes of the Russian Academy of Sciences.

\section{References}

Babenko A. 1994. The taxonomy and distribution of the genus Anurida (collembola: Neanuridae) in the northern Palaeacrtic // European Journal of Entomology. Vol.94. P.511-536.

Bretfeld G. 2000. Third report on Symphypleona from Russia, and also from Georgia, Kazakhstan, Kirghizia, and the Ukraine (Insecta, Collembola) // Abhandlungen und Berichte des Naturkundemuseums, Görlitz. Bd.72. H.1. S.1-57.

Deharveng L. 1987. Revision taxonomique du genre Tetracanthella Schött, 1891 // Travaux du Laboratoire d'Écobiologie des Arthropodes Édaphiques, Toulouse. Vol.5. Fasc.3. P.1-151.

Fjellberg A. 1985. Arctic Collembola I. Alaskan Collembola of the families Poduridae, Hypogastruridae, Odontellidae, Brachystomellidae and Neanuridae // Entomologica Scandinavica, Suppl.21. P.1-126.

Fjellberg A. 1987. Northern species of Onychiurus Gervais, 1841, subgenus Archaphorura Bagnall, 1949 (Collembola: Onychiuridae) // Entomologica Scandinavica. Vol.18. P.279-288.

Huang C.-W., Potapov M. (in press) Taxonomy of the Proisotoma complex. IV. Notes on chaetotaxy of femur and description of new species of Scutisotoma and Weberacantha from Asia // Zootaxa.

Kaprus' I., Pomorski R.J. 2008. Review of the Palaearctic Protaphorura Absolon, 1901 species of octopunctata group (Collembola: Onychiuridae // Annales Zoologici (Warszawa). Vol.58. No.4. P.667-688.

Martynova E.F. 1969. [New species of the family Isotomidae (Collembola) from the Asian part of the USSR] // Zoologichesky Zhurnal. Vol.48. No.9. P.1342-1348 [in Russian].

Martynova E.F. 1970. [New and little known species of Isotomidae and Entomobryidae] // Novye i maloizbestnye vidy fauny Sibiri. Novosibirsk: Nauka. No.3. P.6-16 [in Russian].

Martynova E.F. 1976. [Species of the genus Onychiurus Gervais, 1841 (Collembola, Onychiuridae) of the North and North-East of Asia] // Novye i maloizvestnye vidy fauny Sibiri. Novosibirsk: Nauka. No.10. P.5-44 [in Russian].

Martynova E.F. 1977. [Springtails of the family Tomoceridae in the Far East fauna] // Entomofauna Dalnego Vostoka. Trudy Biologo-Pochvennogo Instituta. Vladivostok: DVNTS AN USSR, Novaya seria. Vol.46. No.149. P.3-16 [in Russian].

Martynova E.F. 1978. [Species of the genus Hypogastrura s.1. (Hypogastruridae, Collembola) new for the fauna of northeastern Siberia] // Novye i maloizvestnye vidy fauny Sibiri. Novosibirsk: Nauka. P.27-46 [in Russian].

Martynova E.F. 1981. [New species of Onychiuridae (Collembola) from Primorski Krai] // Pauki i nasekomye Dal'nego Vostoka SSSR. Vladivostok: DVNTS AN USSR. P.11-18 [in Russian].

Martynova E.F., Gorodkov K.B., Tshelnokov V.G. 1973. [Springtails (Collembola) of Wrangel Island] // Entomologicheskoye obozrenie. Vol.52. No.1. P.76-93 [in Russian].

Martynova E.F., Berman D.I., Tshelnokov V.G. 1977. [To the knowledge of collembolan fauna of southern spurs of Khasyn Mt. Range] // Componenty tundrolesii severnogo Ohotomor'ya. Vladivostok: Nauka. P.102-132 [in Russian].

Martynova E.F., Bondarenko E.P., 1978. [New and little-known Collembolan species of the families Hypogastruridae and Isotomidae from Chukotka] // Novye i maloizvestnye vidy fauny Sibiri. Novosibirsk: Nauka. P.48-58 [in Russian].

Pomorski R.J. 2001. Revue of the genus Hymenaphorura Bagnall, 1948 with descriptions of eleven new species from North America and Siberia // Insect Systematics \& Evolution. Vol.32. P. 439-474.

Potapov M.B. 1997a. Anurophorus species of East Asia and North America // Acta zoologica cracoviensia. Vol.40. No.1. P.1-35.

Potapov M.B. 1997b. New species of Tetracanthella from Asia and North America (Collembola: Isotomidae) // Genus (Wroclaw). Vol.8. No.3-4. P.503-516.

Potapov M. 2001. Synopses on Palaearctic Collembola. Volume 3. Isotomidae. Abhandlungen und Berichte des Naturkundemuseums, Görlitz. Bd.73. H.2. S.1-603.

Potapov M.B., Babenko A.B. 2000. Species of the genus Folsomia (Collembola: Isotomidae) of northern Asia // European Journal of Entomology Vol. 97. No. 1. P. 51-74.

Potapov M.B., Babenko A.B., Fjellberg A. 2006. Taxonomy of the Proisotoma complex. Redefinition of genera and description of new species of Scutisotoma and Weberacantha (Collembola, Isotomidae) // Zootaxa. No.1382. P.1-74.

Schött H. 1893. Zur Systematik und Verbreitung palæarctischer Collembola // Kongl. Svenska Vet. Akademiens Handlingar. Bd.25. H.11. S.1-100.

Tshelnokov V.G. 1977. [New species of the springtail genus Entomobrya (Collembola, Entomobryidae) from the Asiatic part of the USSR] // Zoologichesky Zhurnal. Vol.56. No.7. P.10301037 [in Russian].

Tshelnokov V.G. 1987. [New species of Entomobrya Rondani (Collembola, Entomobryidae) from the Northeastern USSR] // Zoologichesky Zhurnal. Vol.56. No.7. P.1030-1037 [in Russian].

Tshelnokov V.G. 1988. [New species of the springtail genus Anurida Laboulb. (Collembola, Neanuridae) from the Asiatic part of the USSR] // Entomologicheskoye obozrenie. Vol.67. No.1. P.68-87 [in Russian]. 
Tshelnokov V.G. 1990. [A new genus, new or little known species of springtails (Collembola) in the fauna of north-east Asia] // Entomologicheskoe obozrenie. Vol.69. No.2. P.342-351 [in Russian].
Tshelnokov V.G., Bondarenko E.P. 1978. NNew species of the genus Lepidocyrtus Bourlet, 1839 (Collembola, Entomobryidae) from Asiatic part of the USSR] // Novye i maloizvestnye vidy fauny Sibiri. Novosibirsk: Nauka. P.59-63 [in Russian]. 